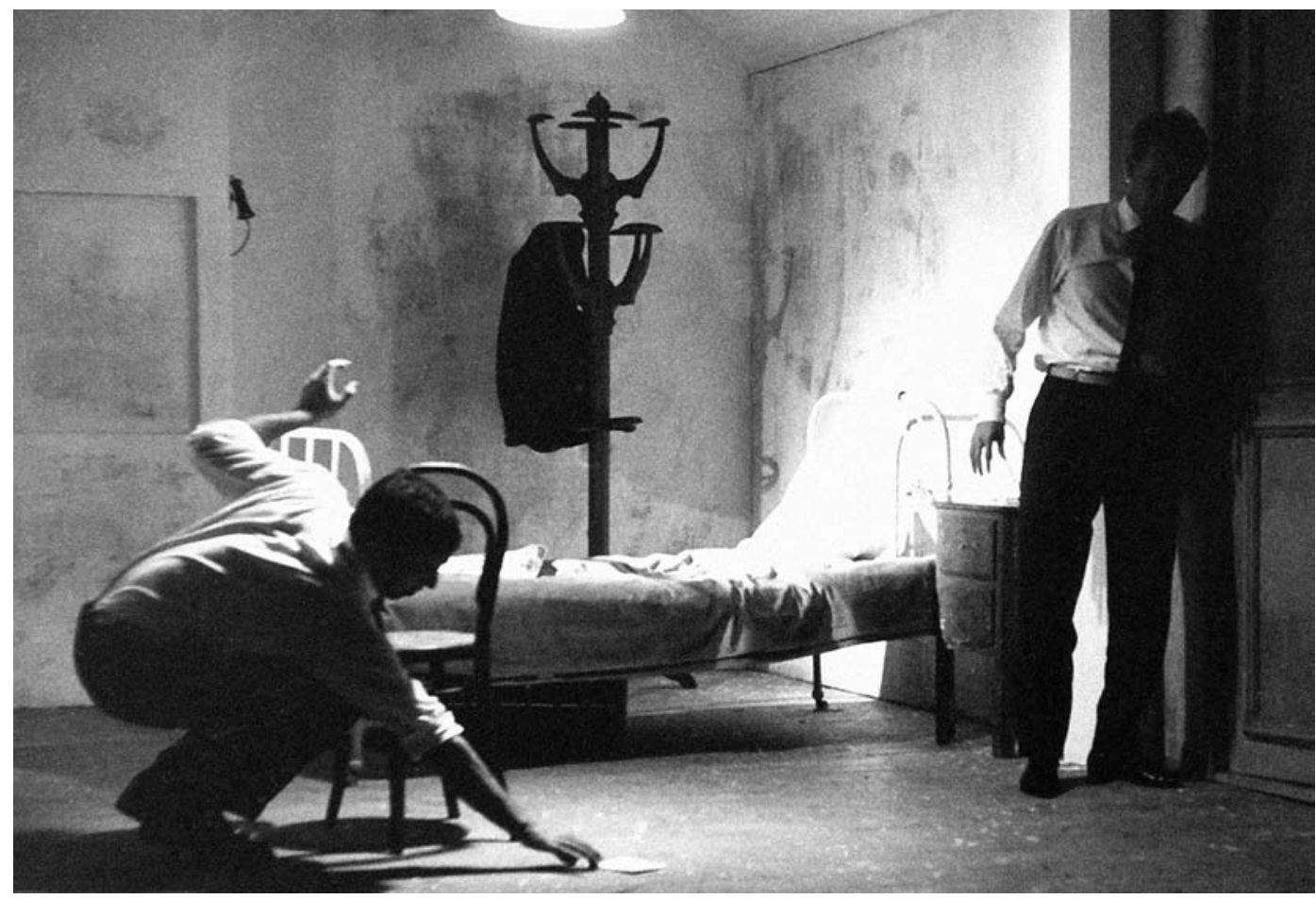

\title{
Humanismo e vitalidade nas peças de Harold Pinter
}

\section{Francis Gillen}

Falar sobre a obra de Harold Pinter é uma lição de humildade. Há sempre alguma coisa que fica por dizer quando acabamos de falar sobre ela. 0 mesmo tipo de ponto de vista que Henry James iniciou no domínio do romance, ou seja, a possibilidade de abertura dada a cada leitor, é o que Harold Pinter faz com o teatro. Uma peça sua é sempre uma colaboração com cada espectador. Como acontece com a grande arte, uma peça de Pinter perturba as nossas certezas mais confortáveis, retira-nos, por assim dizer, dos nossos quartos, inicia um diálogo interior, e, no final, deixa-nos não com um enigma por resolver - porque não há uma visão única ou correcta de Pinter - , mas antes com o mistério essencial da nossa condição humana. Como Pete diz de Shakespeare em Os anões (The Dwarfs): "Punha as coisas a nu, é tudo" (Pinter 2006a: 178).

Quando comecei a publicação de The Pinter Review, em 1987, faz agora vinte e um anos, disse a Harold Pinter que a única coisa que esperava fazer era publicar diversas vozes que pudessem construir pontes para um trabalho que, como sabemos, vive essencialmente no teatro.

Mas todos sabemos também que o teatro renasce em cada novo espectáculo: na colaboração entre autor, actores, e entre aqueles que assinam o desenho de luzes, a encenação, os figurinos e a cenografia; e o elo entre tudo isto e o público: por essa razão, sempre tentei sublinhar na Pinter Review o trabalho feito em teatro. Para além disso, contudo, a alegria de uma revista reside no facto de poder crescer e mudar, partindo das leituras do passado, mas, ao mesmo tempo, reflectindo novas perspectivas sociais, políticas, académicas e culturais. É por isso que considero a obra de Pinter como um grande diamante que vamos continuamente girando para podermos olhar para as suas múltiplas facetas.

Em tempos mais recentes, é o aspecto político da obra de Pinter que vem, muito justamente, motivando uma maior discussão: o modo como ele chama a atenção para a natureza política da linguagem, para o silêncio como uma forma de desacordo, para o fracasso na transmissão de sentido na maior parte dos exercicios de conversação. Falei longamente sobre a política de Pinter no ano passado em Turim, Itália (Gillen 2006), comparando Pinter com os dramaturgos gregos, muito particularmente nas suas críticas impiedosas aos mitos sobre as razões da guerra, e a mortífera mistura de cegueira e poder em qualquer império, seja ele ateniense ou americano. Hoje, contudo, tornou-se óbvio que Pinter tinha razão ao sugerir que falar da sua política pareceria, pelo menos aqui na Europa, falar para os que já estão convertidos. Sobre isso, deixemme só dizer que lamento que, muitas vezes, a discussão sobre a política de Pinter tenha sido reduzida a dizer-se que ele tem razão, enquanto mesmo as suas peças mais abertamente políticas exigem que examinemos a nossa humanidade e reconheçamos até que ponto nós próprios também podemos ser identificados com o poder do torturador e a segurança do grupo.
Francis Gillen

é professor de Literatura Inglesa e Norte-Americana na Universidade de Tampa, na Florida. Autor de diversos livros, é desde 1987 um dos editores da The Pinter Review, publicada por aquela universidade. 
Gostaria aqui de abordar uma das razões por que Harold Pinter será encenado e lido muito tempo depois de esta sinistra guerra ter passado para as páginas da história das infâmias: o humanismo das suas peças e a relação com a vitalidade das suas personagens; o modo como a obra de Pinter, ao pôr a nu a realidade, vai ao âmago da nossa experiência humana.

Não conheço nenhum outro dramaturgo que tenha conseguido dramatizar toda a extensão da nossa preocupação connosco próprios. As suas personagens são movidas por necessidades básicas de que muitas vezes nem sequer têm consciência. Estão prisioneiras dessas preocupações. Recordemos que o próprio Pinter nos disse que quanto mais profunda for a necessidade ou a emoção, menos fácil será articulá-la. E como as necessidades básicas colidem com as necessidades igualmente básicas de um outro ou de outros, temos então as lutas pelo território tão características da sua obra. No seu estudo pioneiro, Austin Quigley (1975) examinou em pormenor as estratégias linguisticas através das quais as personagens de Pinter procuram dominar ou defenderse de ataques, mostrando como o dramaturgo compreende bem que não é a comunicação, mas antes a projecção ou protecção da nossa auto-imagem vital, que ocupa o centro da conversação entre as pessoas. A diferença em Pinter não é a de ter personagens que o digam, mas a de captar isso mesmo no próprio ritmo da língua que falam. Aqui, por exemplo, é a necessidade de Harry em reafirmar a sua superioridade sobre Bill em A colecção (The Collection):

0 Bill é um rapaz que vem dos bairros sórdidos, percebe, tem um sentido de humor sórdido. (...) Há qualquer coisa ligeiramente podre nele, não acha? Como uma lesma. Não há nada de mal nas lesmas quando estão lá nos sitios delas, mas ele é uma lesma dos bairros sórdidos; não há nada de mal com as lesmas dos bairros sórdidos quando estão lá nos sítios delas, mas esta lesma não fica lá no sítio dela - roça-se pelas paredes das casas respeitáveis e larga a sua baba, não é, miúdo? Ele confirma historiazinhas estúpidas e porcas, só para se divertir, enquanto os outros têm de andar às voltas para chegar ao cerne do assunto e acalmar as coisas. Tudo o que ele sabe fazer é ficar sentado, a chupar a puta da mão e a deixar-se apodrecer como a nojenta lesma sórdida que ele é. Que tal mais um whisky, Horne? (Pinter 2002a: 239-240)

Isto é um poeta a criar linguagem no teatro.

Um dos resultados de uma análise como esta é a de ver e geralmente encenar as peças em termos dessas lutas pelo controlo. Assim, por exemplo, em 0 regresso a casa (The Homecoming $)^{1}$, Ruth resiste aos ataques de puro poder patriarcal da família para a qual Teddy a traz e, no momento icónico final, com a cabeça de Teddy no seu colo e Max no chão, é o matriarcado que se afirma. Ou Kate a rejeitar a versão que Anna e Deeley dão dela própria em Há tanto tempo (Old Times), vitoriosa no presente porque agora ela controla o passado.
KATE: (para Anna) Mas eu lembro-me de ti. Lembro-me de ti morta. Pausa.

Lembro-me de ti estendida, morta. Não sabias que eu estava a olhar para ti. Debrucei-me. A tua cara estava suja. Estavas deitada morta, a carta rabiscada com terra, todo género de inscrições sinceras, mas os traços ainda estavam húmidos, e escorriam pela tua cara abaixo, até à garganta. (Pinter 2002b: 60)

Tudo bem por agora, embora eu queira sugerir que isto ainda não vai ao fundo do humanismo de Pinter; com efeito, parece até que a sua obra não joga bem com um termo como este. Examinemos com mais pormenor essa necessidade profunda.

$\mathrm{Na}$ verdade, as personagens de Pinter querem ser alguém, querem ter um sentido, saber que não são um nada, que não são destituidas de valor. Esforçam-se por ser verdadeiras consigo próprias, especialmente as mulheres de Pinter, embora também elas exijam a existência do "outro".

Em primeiro lugar, como Pinter mostra especialmente em Os anões, as nossas impressões são tão fugidias e fantasmagóricas que a própria identidade pode bem depender da sua verificação por um outro. É, a este propósito, muitas vezes citada a réplica de Len nessa peça:

Aquilo que és, ou aparentas ser para mim, ou aparentas ser para ti, muda tão rapidamente, tão horrivelmente que não o consigo acompanhar e tenho a certeza absoluta que tu também não. (...) Onde é que procuro, o que é que há para procurar, para ter algumas certezas, para poder escansar um bocado desta confusão do caraças? És a soma de tantos reflexos. Quantos reflexos? Reflexos de quem? É disso que és feito? Que espuma é que a maré leva? (...) 0 que é que eu vi, a espuma ou a essência? (Pinter 2006: 108-109)

Para além disso, todavia, o sentido depende até certo ponto de um outro, sim, mas para ser eu aos olhos de um outro que afirma o meu sentido. Como Sebastian Moore escreve num contexto diferente: "o instinto de sobrevivência, tornado humano, é o sentido do valor pessoal. 'Eis-me aqui' significa isso mesmo: eis-me aqui e tu não podes ignorar-me". 0 "tu" nesta frase implica uma relação. $E_{1}$ assim, o paradoxo é, muitas vezes, em Pinter, que a própria necessidade que cada um tem de se defender, ou de defender o seu território, acaba por, ao mesmo tempo, criar uma distância ou malquerer por parte daqueles que precisamos e desejamos que confirmem a nossa existência e sentido.

Em terceiro lugar, a preocupação das personagens de Pinter consigo próprias é muitas vezes o produto das necessidades que estão em permanente mudança e conflito. Em parte alguma isto é mais visivel do que na personagem de Ruth em 0 regresso a casa. Ela tinha sido um "modelo do corpo" e a necessidade profunda de realização sexual, que o seu marido Teddy parece relutante ou incapaz de garantir, é visivel na sua decisão de continuar ali com os seus enteados, aparentemente, pelo menos no entender 


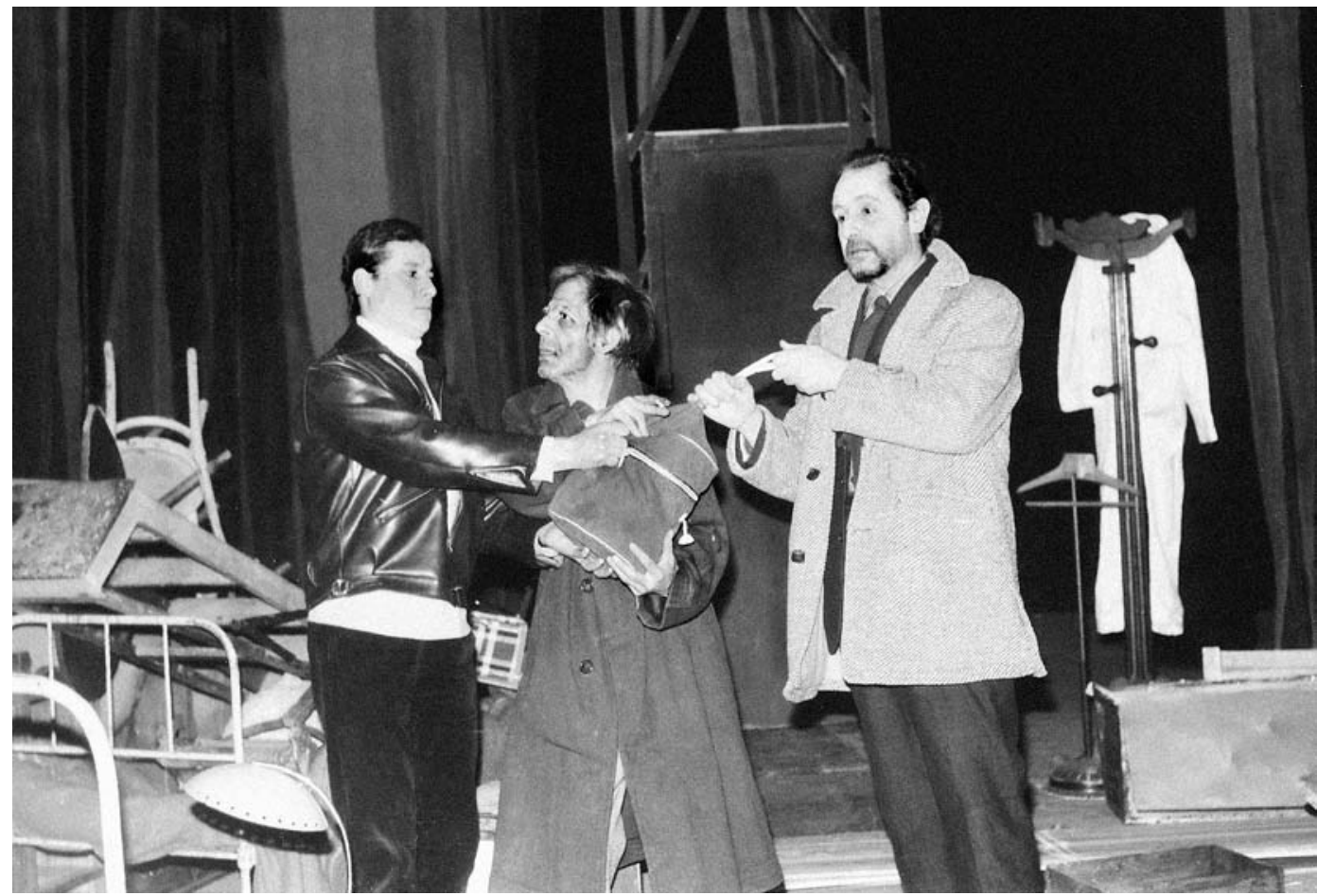

deles, para suprir as suas necessidades, ao mesmo tempo que ganha a vida como prostituta em tempo parcial num dos apartamentos de Lenny na rua Greek. De facto, é claro que é ela, e não eles, quem dita as suas próprias regras, e muitos críticos vêem-na como triunfando sobre as personagens masculinas. Depois vem uma réplica, uma das minhas favoritas, que parece surgir não se sabe de onde: "Não te tornes num desconhecido" (Pinter 2002c: 337), diz Ruth a Teddy quando ele parte para a América, indicando que reconhece as necessidades de ordem e distância para lá do negócio que fez. Pinter disse uma vez, com razão, que 0 regresso a casa é uma peça sobre o amor, mas, como acontece com muitas outras necessidades nas peças de Pinter, temos consciência disso principalmente através da sua ausência, neste caso a presença de um "outro" que podia confirmar ambos os lados de Ruth, a sua capacidade para o amor tanto sexual como espiritual, erose agape.

Há uma solidão - e uma ausência - terrivel, existencial, nas peças de Pinter, que não estaria lá se se tratasse apenas de apresentar lutas pelo poder, e as boas encenações dãonos tanto essa luta como essa ausência, de forma ainda mais palpável por as ausências estarem tanto por detrás do que é dito, como nos silêncios, tal como um dente cariado só é sentido através da dor. A famosa "pausa" pinteriana não é apenas uma estratégia: deve ser a presença sentida no palco daquilo que está ausente. Pinter mostranos seres humanos, no âmago de nós próprios, como um feixe de necessidades insatisfeitas, desejos movediços, muitas vezes incerteza sem remorso acerca do que somos ou de quem somos, e contudo, de forma paradoxal - e aqui está uma das fontes do seu humor - envolvidos em lutas pelo território para promover e defender aquele relance momentâneo, incompleto, do que somos, e nessa luta, a maior parte das vezes, afastando-nos justamente das pessoas de que precisamos para que nos confirmem esses relances de nós próprios. De facto, os pretensos vitoriosos na luta pelo território são muitas vezes os mais dilacerados, como Goldberg em Feliz aniversário (The Birthday Party) $)^{2}$ e até Ruth, que conscientemente e com intenção de se auto-preservar, se ergue na familia como a Rute bíblica, "sozinha no meio da eira alheia".

0 mais profundo humanismo mostra-nos, creio, pessoas no seu pior, com todos os seus defeitos e fracassos, e, contudo, não nos deixa sem esperança. Alguns meses atrás, alguém me perguntou durante o jantar por que razão não considerava eu que Pinter era um dramaturgo do absurdo, e eu respondi que no seu caso, diversamente do que acontece, por exemplo, em lonesco, há uma ideia de que as coisas não têm de ser como são. É certo que mesmo no absurdo há a declaração de Camus no Mito de Sísifo de que, em todos os actos de reconhecimento do absurdo, muitas vezes na arte, nós somos capazes de 0 transcender. É o que acontece também com Pinter, mas creio que ele vai mais longe do que isso. Deixem-me regressar então àquele fugaz relance de esperança e afirmação no mundo das personagens de Pinter.

Primeiro que tudo, desde o romance Os anões Pinter reconhece a possibilidade de que podemos - e várias vezes afirmamos - a identidade do outro. Essa é, na prática, a razão pela qual Michael Billington regista de forma tão convincente na sua biografia o modo como a amizade para Pinter é tão importante quanto a traição é desprezivel. No romance, os três jovens, vagamente baseados no próprio Pinter e em dois dos seus amigos mais intimos e mais antigos, conseguiram criar no passado um contexto em que, apesar da rivalidade e da diferença de personalidades, cada um pode afirmar-se e, ao mesmo tempo, ver reconhecido o seu valor pelos outros. Pete chama-lhe uma "igreja":

Dificilmente se poderia dizer que partilhassem um dogma ou uma orientação, mas havia um terreno comum e havia uma estrutura. Nos bons momentos formavam uma unidade que, a seu ver, tinha caracteristicas para se poder considerar uma igreja; uma aliança dos três pelo bem comum, e uma fé nessa aliança. (Pinter 2006a: 77)
${ }^{2}$ Veja-se a tradução de Artur Ramos e Jaime Salazar Sampaio, realizada em 1967 e publicada em Teatro l, op. cit., pp. 35-108 (N.T.).

${ }^{3}$ Ver artigo de Mark-Taylor Batty neste número da Sinais de cena (N.T.). 


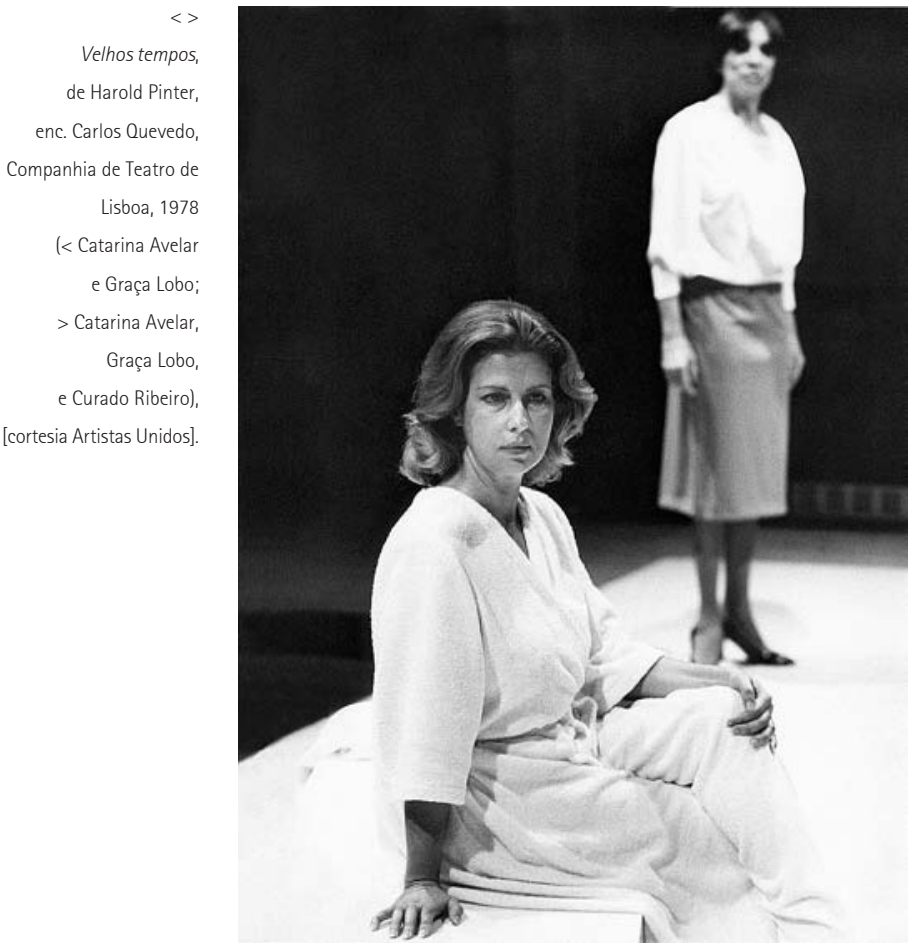

Nas peças, essa moldura é geralmente mais visível pela sua ausência, mas está presente na observação de Ruth a Teddy, que citei atrás, sugerindo que há uma moldura mais ampla do que o facto de ser deixada para trás poderia dar a entender, no olhar silencioso que os dois irmãos, Mick e Astin, trocam entre si no final do 0 encarregado (The Caretaker) ${ }^{4}, \mathrm{e}, \mathrm{creio}$, na graça sugerida pela presença de Bridget em Luz da lua (Moonlight).

Em terceiro lugar, e isto é o mais importante para compreendermos Pinter, muitas das suas personagens estão "em processo" de se constituirem. Tornou-se axiomático que nada sabemos das personagens antes de entrarem em palco e nada também depois de saírem de cena. Porque a pessoa humana na obra de Pinter está limitada a relances parciais e incompletos do que são e do que são os outros, há, num momento qualquer, uma incompletude que acompanha, eu avançaria, um impulso para a completude que está presente nas suas personagens vitais, mas que surge substituido ou sublimado nas suas personagens menos vitais. (Vimos esse impulso para a completude na réplica de Ruth a Teddy: "Não te tornes num desconhecido"). Em Pinter, todavia, um tal movimento não vai no sentido do significado clássico, de Aristóteles, de um equilíbrio entre extremos, mas é antes um movimento de um estado para o outro. Na memória do início da sua vida, "A rainha de todas as fadas" ("The Queen of All the Faeries"), composta quando tinha 21 anos, Pinter censura os que "sempre ficam nos limites de um mundo, de um plano". Numa entrevista dada a Michael Billington em 1993, comentou como era difícil "suster e manter um equilibrio" acrescentando: "Há uma espécie de suavidade que eu não consigo compreender de todo. Uma resignação talvez relativamente a um estado de coisas que pessoalmente acho infinitamente doloroso e, de algum modo, intolerável".

Quando Harold Pinter publicou o seu romance juvenil Os anões, em 1990, cortou cinco dos capítulos que, como escreveu numa prefacial "Nota do autor", Ihe "pareceram redundantes" (Pinter 2006a: 9). Pinter tinha-me deixado

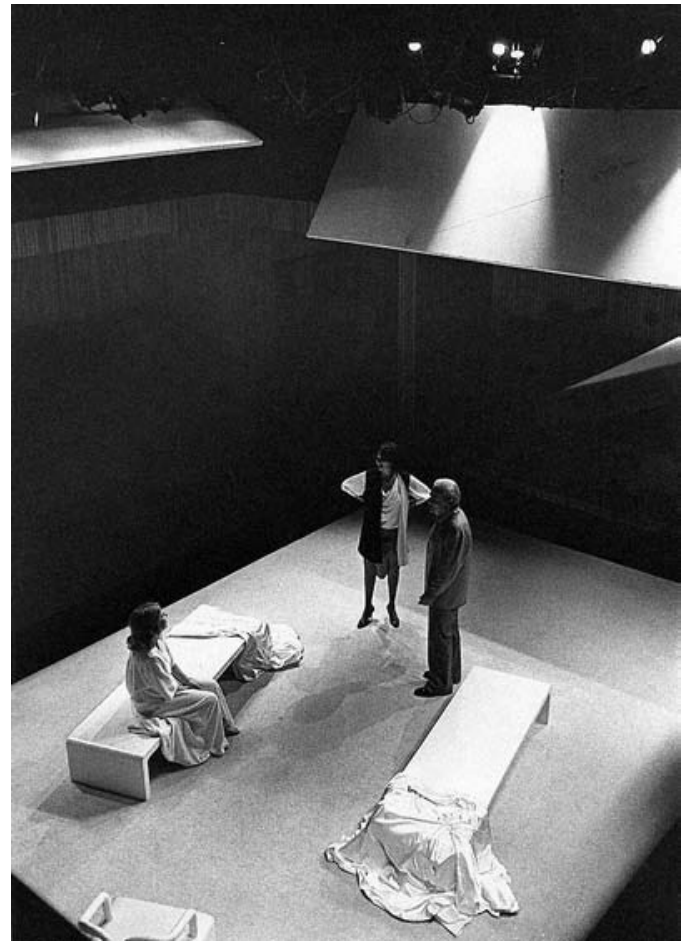

ler o romance original em 1984 e, portanto, a minha memória do romance incluía a de um notável capítulo 28 em que Pinter descreve muito directamente o impulso de crescimento que encontramos em muitas das suas obras. Do ponto de vista romanesco, Pinter teve toda a razão em suprimir o capítulo, uma vez que ele não contribuia para o avanço do movimento da obra. Do ponto de vista da crítica, o capítulo pode ser útil a ajudar-nos a apreciar uma parte do impulso criativo do teatro de Pinter.

0 capitulo 28 do romance original descreve uma viagem feita justamente quando o narrador está prestes a deixar um dos patamares da sua vida. De repente, o caminho é totalmente diferente do que esperava, embora haja "em certos aspectos da paisagem uma aproximação a algo que eu em tempos conheci", apesar de as suas experiências até essa altura terem tido um "carácter muito estranho a tais aparências". Descreve-se muitas vezes como "estático" ou apático, enquanto uma outra força, "uma grande estrela" parece "implacável no seu poder". Este novo estado, que parece opor-se ao seu velho estado, está simplesmente presente, sem causa aparente ou lógica. Não pode adaptar-se a nenhum dos conceitos ou linguagem conhecidos:

[0]u por qualquer coisa ou a partir de qualquer coisa, ou por qualquer coisa, não posso dizer; com que intenções, com que precauções, com que implicações precisas; se de propósito ou acidentalmente ou por ignorância; com que tendência, com que defeito, com que faculdades; por que atractivo, por que apelo, por que deslealdade: estes factores ignoro-os. Um acabou, e o outro, apenas num breve periodo de tempo, começou.

Tenta então impor condições e essas condições aceitam o carácter de "outro" dos mortos:

E as condições que impus ao morto foram as de que, se, do seu lugar seguro, fosse chamado a participar ou a agir, não era de modo algum para ser diferenciado, ou para considerar a simpatia como uma 


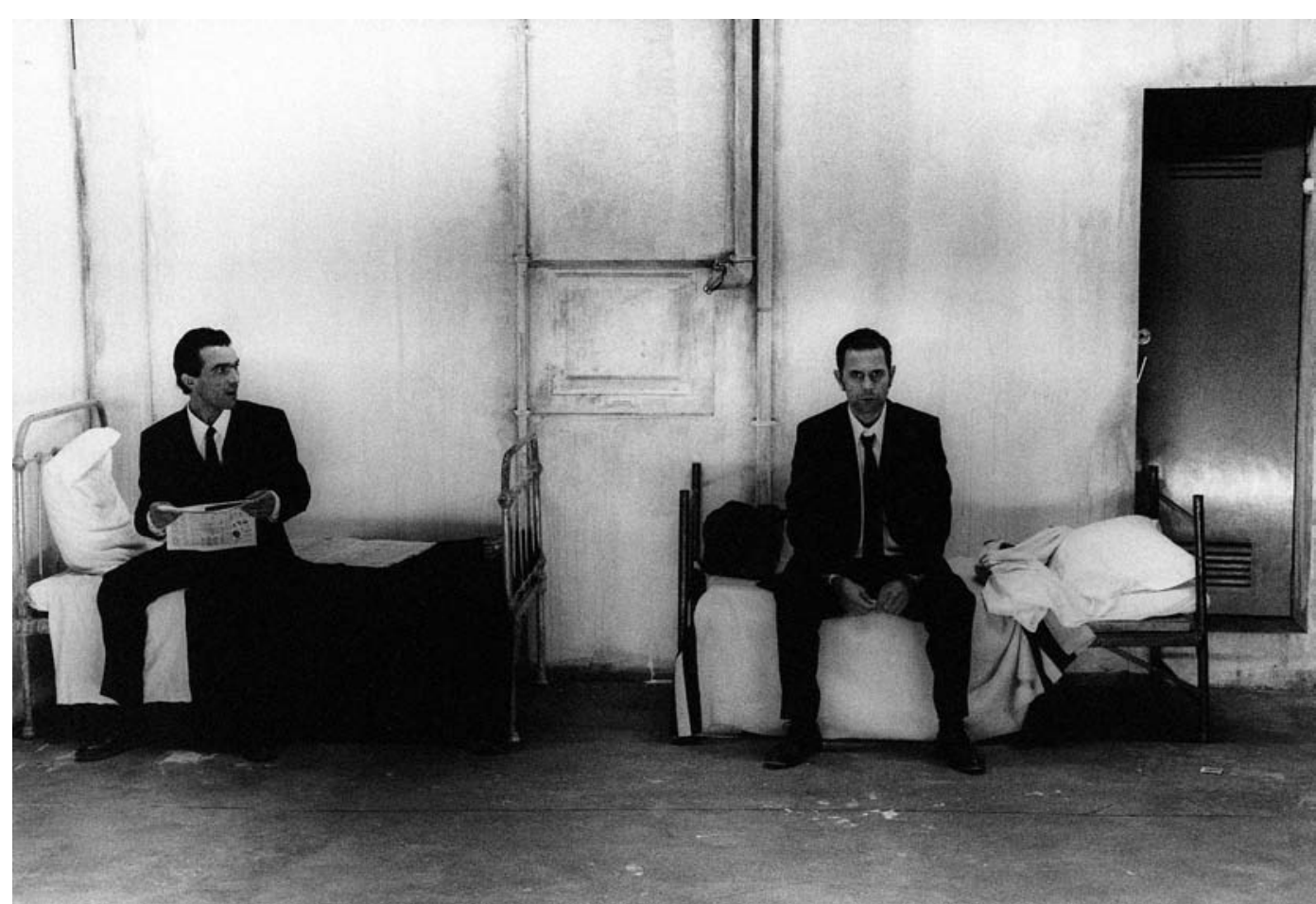

qualidade, ou a diplomacia como um método, ou a caridade como virtude. Nem era para persuadir, nem esclarecer, nem preocupar-se com a conclusão ou a verificação, nem manter equilibrio ou liberalidade na sua estratégia, nem julgar ou comentar, nem sofrer dor ou arrependimento nem, de algum modo, usar da compreensão, mas antes sufocar ou rejeitar todas as inclinações nesse sentido.

Mais tarde, contudo, chega uma altura em que ele é obrigado a referir-se a esse morto:

E na longa viagem impus-lhes essas condições, e mais tarde, muito mais tarde, cheguei ao ponto em que fui obrigado a referir-me ao meu morto, e a trazê-lo do seu lugar seguro, e chamá-lo à acção, e, como foi óbvio, juntar-me a ele na observação, enquanto continuava a "viver com o meu outro" e a conformar-me com a sua politica, um traidor no meio de mim próprio. Até que mais tarde, muito mais tarde, quando a grande estrela se tinha deslocado, quando eu já não estava parado, quando a disrupção se tinha instalado, vi a situação alargarse e alongar-se e ganhar profundidade na sua alteração.

Entre este nascimento e esta morte. Pensemos nisto. Pensemos como a frase descreve com grande clareza o movimento de afirmação de vida em muitas das personagens de Pinter. É mais óbvio nas peças cíclicas de deslocação, Uma ligeira dor (A Slight Ache) $)^{5}$ e A cave (The Basement $)^{6}$, assim como é mais abstracto nos contos "Kullus" e "O exame" ("The Examination") 7 .

0 padrão mais frequente é, todavia, o da chegada de alguém ou alguma coisa, externa ou interna, que ameaça o status quo, os compromissos e as evasões, que vamos fazendo em nome do eu. Os quartos de Pinter são mais frequentemente internos do que externos, e, mesmo quando a ameaça parece vir de fora, as ameaças externas são imagens especulares de uma qualquer necessidade ou medo inarticulado dentro do individuo. Noutro sítio, explorei isto em termos do conceito de sombra do psicólogo Jung. Em 0 serviço (The Dumb Waiter) ${ }^{8}$, por exemplo, o equilibrio de Gus é perturbado pela memória da rapariga que tinham "despachado", e as exigências crescentes de comida cada vez mais exótica são imagens brilhantes do desconforto crescente mas inarticulado de Gus com o que se the exige no seu papel de assassino, a culminar num grito angustiado que se aproxima de uma forma de morte: "Já não temos nada! Nada! Estão a compreender?" (Pinter 2002d: 138). Eis o exemplo de uma réplica que faz todo o sentido numa peça de gangsters, e, contudo, traz consigo um peso incrivel de sentido emocional e simbólico!

Para citar mais alguns exemplos do estatuto de ser desafiado: a presença de Anna em Há tanto tempo representando uma Kate mais viva e sensual que Deeley acha que falta, a revelação em Traições (Betrayal) $)^{9}$ de que Emma tinha contado há muito tempo a Robert da sua relação com Jerry; a história de Stella de uma relação em A colecção; a capacidade de Spooner de entrar nas memórias de Hirst e, portanto, desafiar aquilo que ele pensara ser um passado firme e auto-afirmativo, mesmo se vai e vem nos seus estados de embriaguês.

Há custos para esta vitalidade. Pensem na terrivel separação existencial de Kate no fim de Há tanto tempo, de forma tão competente tornada visivel por Pinter nos divãs separados; ou, como dissemos antes, de Ruth, em 0 regresso a casa; de Stanley, e, também, de Petey, em Feliz aniversário; de Bel, no final de Luz da lua; de Rebecca, em Cinza às cinzas, de pé na fronteira desconhecida entre empatia e loucura.

Há também implicações linguisticas e culturais. Porque a necessidade vem de alguma coisa interior, muito profunda, de regiões inexploradas, mas sentidas como subconscientes, algo que é essencialmente da ordem do privado e não tem linguagem disponivel e, com toda a certeza, nenhuma convenção social definida. Na cultura ocidental ainda patriarcal dos anos 60 do séc. $X X$, altura em que foi escrita a peça $O$ regresso a casa, não havia nenhuma linguagem ou moda para unir os dois lados de Ruth; em Há tanto tempo, tanto a cultura como a língua afirmam o lado feminino de Anna, e a falta de linguagem para descrever
O serviço,

de Harold Pinter, enc. Vitor Correia e João Saboga, Artistas Unidos, 2001 (Vitor Correia e João Saboga), fot. Jorge Gonçalves.

${ }^{5}$ Veja-se a tradução de Pedro Marques publicada em Os anões e outras peças, Vila Nova de Famalicão, Edições Quasi, 2006, pp. 7-39 (N.T.).

${ }^{6}$ Veja-se a tradução de Pedro Marques

publicada em Os anões e outras peças, op. cit., pp. 201-221 (N.T.).

${ }^{7}$ Também traduzido por "O interrogatório" por João Paulo Esteves da Silva e publicado in Vórias Vozes, Vila Nova de Famalicão, Edições Quasi, 2006, pp. 93-98 (N.T.).

${ }^{8}$ Veja-se a tradução de Pedro Marques e João Saboga, publicada em Teatro I, op. cit., pp. 109140. A mesma peça foi estreada entre nós sob o titulo de 0 montacargas, em 1963, com tradução de Luis de Sttau Monteiro (N.T.).

${ }^{9}$ Veja-se a tradução de Berta Correia Ribeiro, realizada em 1984 e publicada em Harold Pinter, Teatro II, Lisboa, Relógio d'Água, 2002, pp. 115-166 (N.T.). 

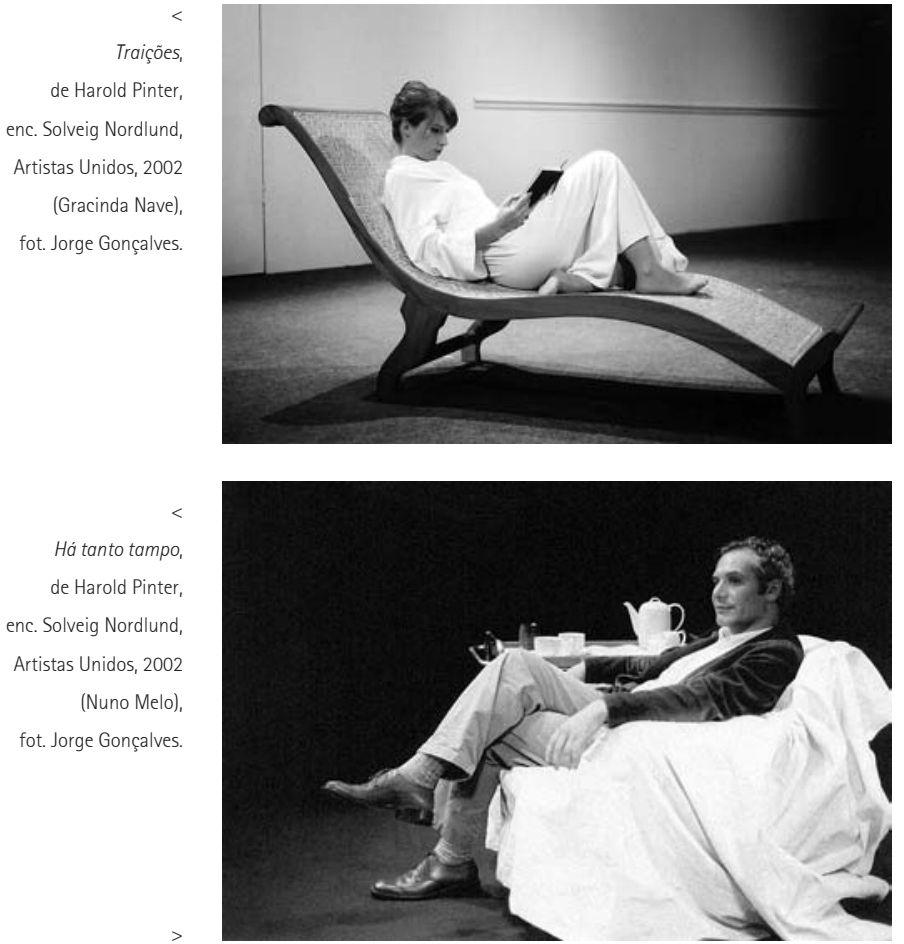

A colecção,

de Harold Pinter enc. Artur Ramos, Artistas Unidos, 2002

(Teresa Sobral), fot. Jorge Gonçalves.

o que Rebecca sente e sabe sobre a ligação, em Cinza às cinzas, leva o seu marido amante a assumir uma forma de loucura de que ela tem de ser salva.

E isso leva-nos de volta ao lugar onde começámos: 0 político. Quando compreendemos a terrivel separação existencial e a solidão das personagens de Pinter que caracterizei como vitais, aquelas que são capazes de aceitar as nossas vidas humanas como uma viagem entre estados de ser separados e incompletos, percebemos melhor a contra-atracção que pode surgir pelas certezas que provêm de um compromissso total com um partido, um clube, um país, um grupo ou uma cultura. Ai não temos de criar uma linguagem porque ela existe já para nós usarmos préempacotada, com todas as palavras de código de que precisamos para sermos membros do grupo ou da cultura: tanto grupos grandes - como "Deus salve a rainha", "Deus abençoe a América", "Apoiem as nossas tropas", "Só a vitória é opção" -, como grupos pequenos ou opções, com as suas próprias palavras culturalmente codificadas e culturalmente irrepreensiveis; até aos grupos de críticos que olham para Pinter de uma maneira ou de outra. Experimentem uma peça como Tempo de festa (Party Time) para saber o que significa ser e estar num clube.

Na festa, palavras ou frases como "puro conforto", "classe a sério" ou "primeira classe" definem a assunção isolada e inata de razão, de saber "o que Deus quis para a raça humana" dos que frequentam a festa. Como diz Liz: "Eu quero ser parte da sociedade das pessoas bem vestidas? Por Deus, eu não sei, elegância, estilo, graça..." (Pinter 1998: 299). A festa só é ligeiramente perturbada por um qualquer protesto que decorre lá fora, e a preocupação de Dusty pelo seu irmão que está lá fora. 0 preço da festa? Cegueira voluntária ao que se passa lá fora. Como Terry, o marido de Dusty Ihe diz:

${ }^{10}$ Veja-se a tradução de Paulo Eduardo Carvalho,

publicada in Teatro II, op. cit., pp. 207-227 (N.T.).
Não tens de acreditar em qualquer coisa. Tu só tens que te calares tratares das tuas coisas (...). Vieste a uma festa encantadora como esta e tudo o que tens a fazer é calares-te e gozar a hospitalidade e

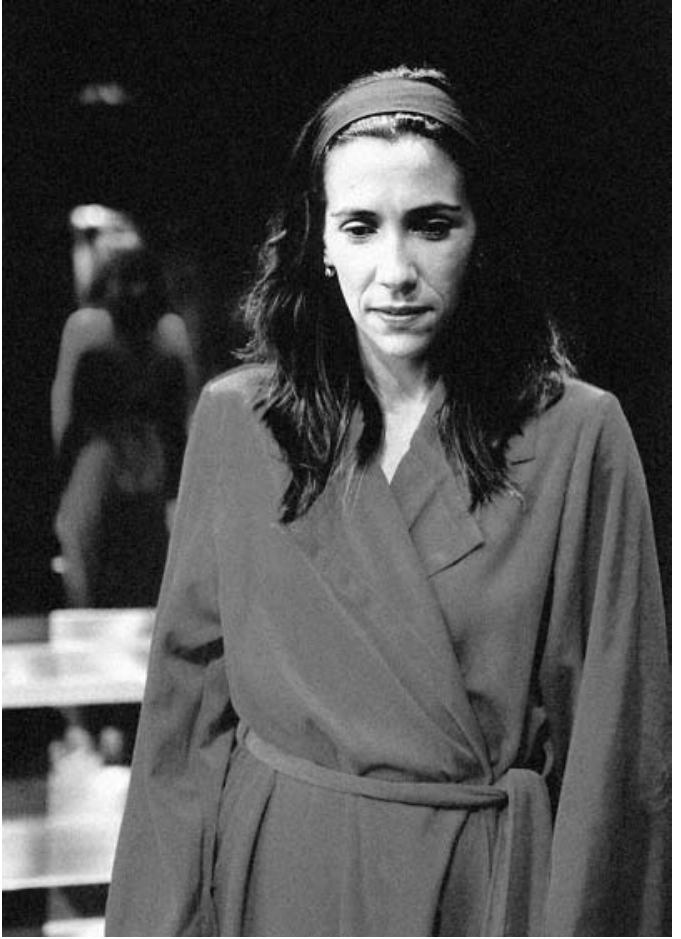

preocupares-te com a merda das tuas coisas. (...) Estás sempre a dar ouvidos a todas essas coisas espalhadas por sacanas sobre sacanas. 0 que é que isso tem a ver contigo? (Ibidem: 287-288)

Fred e Douglas são os protectores desta cega serenidade. Reconhecendo e elevando o punho cerrado do fascismo, Douglas declara:

Queremos paz e vamos tê-la. Mas queremos que seja uma paz de ferro. Sem fugas. Sem concessões. De ferro. Tudo a direito. Esse é o tipo de paz que queremos e é o tipo de paz que vamos ter. Uma paz de ferro. (Ibidem: 292-293)

0 que está presente nesta festa é a entropia, mais do que a vitalidade, um agarrar-se ao status quo com todos os privilégios que isso implica, e a vontade de usar a força, a força inflexível, disfarçada de uma determinação de preservar "valores". Como afirmam os torturadores e os que vendem os seus serviços para impor a força nas peças abertamente políticas de Pinter, há uma "pureza" nisso.

Finalmente, deixem-me ilustrar de forma breve este processo numa das peças de Pinter, Cinza às cinzas (Ashes to Ashes $)^{10}$. Primeiro, o cenário: casa de campo, um jardim nas traseiras. A mobília sugere o conforto de uma classe média alta. No palco, duas pessoas da classe média normal, na casa dos quarenta, de nome Devlin e Rebecca, embora nunca nomeadas durante a representação. 0 desenho de luz: luz no exterior no início da peça. Muito semelhante à intensidade dentro.

Enquanto o casal fala, torna-se claro que alguma coisa perturbou Rebecca. 0 que inspirou a escrita da peça a Pinter foi ter lido a biografia - da autoria de Gitta Sereny - de Albert Speer, o arquitecto de Hitler que desenhou as fábricas de trabalho escravo da Alemanha nazi, e depois ficou horrorizado pelo que viu quando as visitou, mas o público desconhece isso. Contudo, alguma coisa perturbou o que quer que houvesse de equilibrio anterior entre os dois. Nos rascunhos que se encontram no arquivo de 


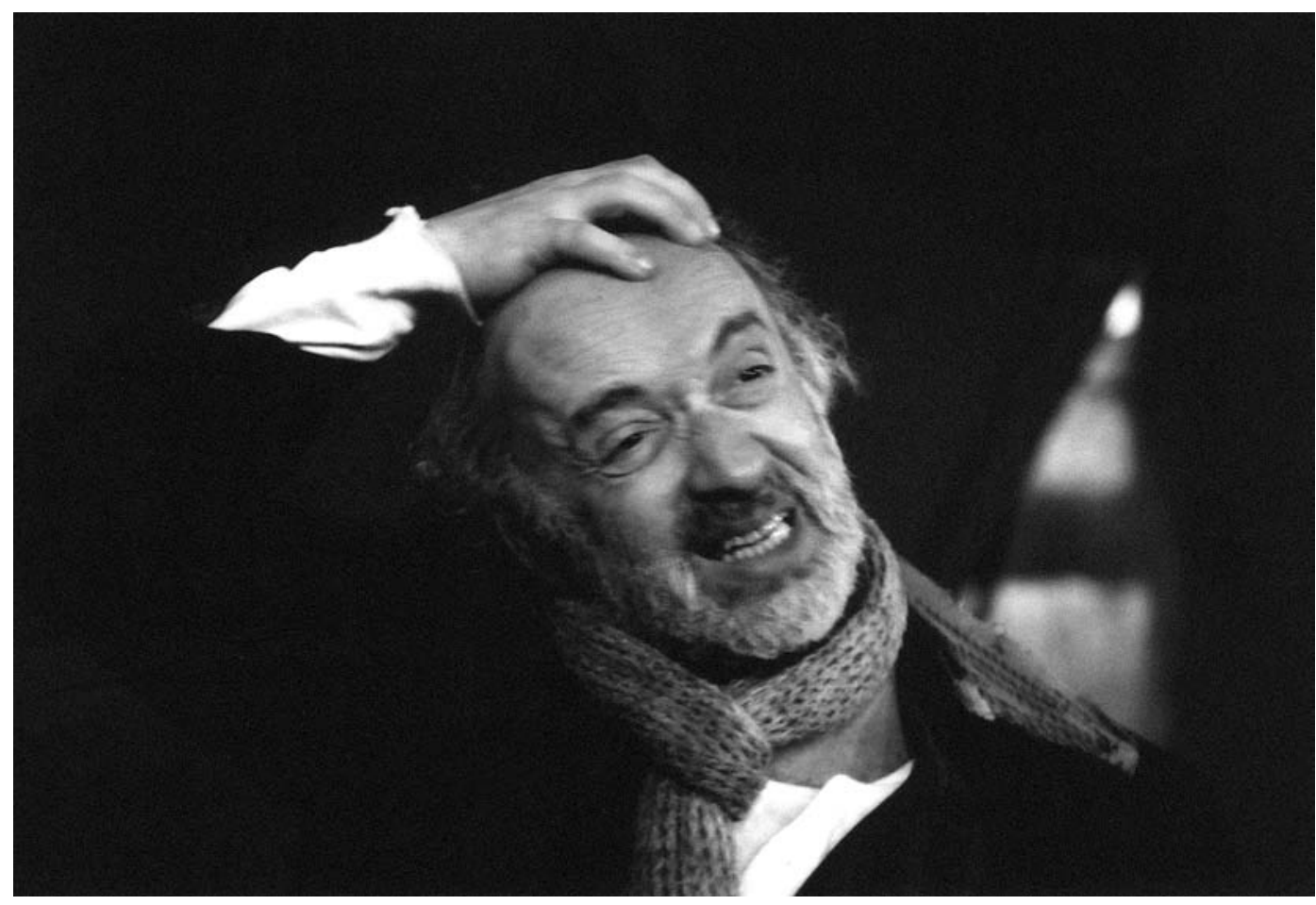

Pinter, na British Library, é claro que são marido e mulher. Na versão final, Pinter removeu essa especificidade. Rebecca fala sobre um homem que refere como seu amante, 0 modo como ele a obrigava a beijar o seu punho fechado e depois punha as suas mãos à volta do seu pescoço.

REBECCA: Por exemplo... ele deixava-se ficar de pé, à minha frente, e cerrava o punho. E depois punha a sua outra mão no meu pescoço, agarrava-o e empurrava a minha cabeça até si. Roçava o seu punho... sobre a minha boca. E dizia:"Beija o punho".

DEVLIN: E tu beijavas?

REBECCA: Oh, claro. Beijava-Ihe o punho. Os nós dos dedos. E depois ele abria a mão e oferecia-me a palma da mão... para eu beijar... e eu beijava-a.

Pausa.

E depois eu falava.

DEVLIN: E o que dizias? Dizias o quê? Dizias-Ihe o quê?

\section{Pausa.}

REBECCA: Eu dizia. "Põe a tua mão à volta da minha garganta".

Murmurava através da sua mão, enquanto a beijava, mas ele ouvia

a minha voz, ouvia-a através da sua mão, sentia a minha voz na sua mão, ouvia-a ali.

Silêncio.

DEVLIN: E ele punha? Ele punha a mão à volta do teu pescoço? REBECCA: Oh, claro. Punha. Claro. E mantinha-a ali, delicadamente, muito, muito delicadamente, tão delicadamente. Ele adorava-me, estás a perceber?

DEVLIN: Adorava-te?

Pausa.

E isso significa o quê?, "ele adorava-te"? 0 que é que isso significa? Pausa.

Queres tu dizer que ele não colocava qualquer pressão sobre a tua garganta? É isso que tu queres dizer?

\section{REBECCA: Não.}

DEVLIN: Então o quê? 0 que é que tu queres dizer?

REBECCA: Ele exercia alguma... pressão... sobre a minha garganta, claro. De tal modo que a minha cabeça começava a cair para trás, delicada, mas expressivamente...
DEVLIN: E o teu corpo? Para onde caía o teu corpo? REBECCA: 0 meu corpo caía para trás, lenta, mas expressivamente. DEVLIN: De tal modo que as tuas pernas se abriam? REBECCA: Sim.

Pausa.

DEVLIN: As tuas pernas abriam-se?

REBECCA: Sim.

Silêncio. (Pinter 2002e: 209-210)

Devlin, pelo seu lado, depois de the assegurar que ela nunca mais ficará sem uma sirene de polícia, tenta reorientar a conversa de modo a que possa "focalizá-la". Pelo contrário, ela replica com a história de uma caneta que caiu de uma mesa e, depois, uma outra de pessoas que seguiam guias - uma palavra que tinha usado antes para descrever o homem com as suas mãos em volta do seu pescoço - na direç̧ão do mar. Devlin, entretanto, reage com o conceito lógico de autoridade, primeiro de Deus, e depois a falta de autoridade dela para falar sobre o sofrimento, porque ela nunca o teria experimentado... Ele tenta distraí-la com coisas banais e vulgares: a cidade, um filme, a familia, os filhos da irmã dela, mas as suas histórias levam-na à questão da responsabilidade pelo mal, e mais importante ainda, às razões para se ter afastado de um homem num cinema.

REBECCA: Mas estava um homem sentado à minha frente, do meu lado direito. Esteve completamente imóvel durante o filme todo. Nunca se mexeu, estava rigido, como um corpo com rigor mortis, não se riu uma única vez, estava ali sentado como um cadáver. (Ibidem: 223).

É evidente que a morte e a a paralisia (stasis) têm estado relacionados com a percepção de Rebecca e ela começa a distanciar-se de Devlin tal como fez relativamente ao homem no cinema. Ele tenta começar outra vez, declarando em frases curtas, factuais, o que julga serem os factos da vida dela. Ela responde utilizando palavras que lembram 
aquele 28. capítulo citado atrás: "Não me parece que possamos recomeçar. Nós já começámos... há muito tempo atrás. Começámos. Não podemos começar 'outra vez'. Podemos acabar outra vez" (Ibidem: 223).

Liberta agora do presente de Devlin, Rebecca está assim livre para se entregar à sua sombra privada e comunitária que culmina na confissão que faz da sua culpa. A história começa, como é normal, com a sombra, como a de uma outra mulher, uma terceira pessoa, ela, que entregou uma criança às autoridades fascistas, e termina com o "eu": "A bebé respirava. (...) Encostei-a a mim. Ela respirava. 0 seu coração estava a bater" (Ibidem: 225). Devlin identifica-se com o amante e ordena que ela beije o seu punho fechado, mas ele está a falar da antiga Rebecca e as suas ordens são esvaziadas com o silêncio dela. Então ela "é" a sua culpa, uma culpa que ecoa, enquanto ela conta como desistiu e negou a sua filha:

REBECCA: Eu não tenho nenhum bebé.

ECO: Nenhum bebé.

REBECCA: Não sei de bebé nenhum.

ECO: Bebé nenhum. (Ibidem: 227)

A peça progride obliquamente, mas é ai que está a questão. 0 inconsciente pessoal e comunitário só pode ser expresso através de uma história e de um símbolo porque só eles podem exprimir um horror que, como o próprio Pinter refere, aterroriza porque foi pensado de forma tão lógica. Cada história aproxima Rebecca mais e mais dessa sombra, tal como cada apelo à lógica e à ordem - e finalmente à força - conduz Devlin para mais longe da sombra dele.

Durante a parte final da peça, a luz lá fora vai-se esbatendo até desaparecer, enquanto que no interior se vai tornando cada vez mais intensa. Estamos, claramente, cada vez mais dentro da mente de Rebecca, ou de alquém assombrado pela memória de atrocidades - com as imagens de pesadelo das pessoas empurradas de cima das rochas, com o gelo cobrindo as ruas e os bebés arrancados dos braços das suas mães.

Rebecca é muitas vezes descrita como heroína e Devlin como um vilão. De facto, a peça de Pinter faz-nos ver a nós próprios em ambos. A possibilidade de empatia, a identificação com os que sofrem e são oprimidos, com as vitimas. Mas também a atracção, afinal, pela força. Tendo usado todos os argumentos e estratégias - apelos à lógica, a Deus, à família, mesmo ao desmerecimento que resulta de ela nunca ter sofrido - e tendo falhado na intenção de restaurá-la para o "vulgar e aceitável" -, ele regressa à força. Como isso é tão humano! Pensem na insistência de Arthur Miller em Depois da queda (After the Fall) que nós nunca compreenderiamos a atrocidade enquanto não víssemos em nós próprios um potencial tanto de vítima como de agressor. A diferença dramática é que Miller põe as suas personagens a dizê-lo. Pinter dramatiza a escolha.

Penso mesmo que ele usa a estrutura física do teatro aqui. Quando saimos do teatro para regressar às nossas vidas normais, ou para tomar um copo ou ir jantar depois do teatro, também nós, como espectadores, podemos hoje identificarmo-nos com os bebés arrancados dos braços das mães no Darfur, mas estaremos muito mais aptos a fazê-lo se, como acontece a Rebecca, o "eles" se tornar "eu" e reconhecermos as nossas próprias tendências sadomasoquistas.

Pinter não nos prega isto. Ele não o diz. Dá-Ihe corpo na acção dramática e confronta-nos com a escolha.

Este é o exemplo do humanismo de Pinter. Mostrar o pior em nós como humanos, mas insistir na nossa liberdade de escolher, por mais atormentada e assustadora que possa ser essa viagem para dentro de nós próprios e, talvez, para a nossa sombra. Ou aceitar o conforto e o poder partilhado da linguagem, autoridade, pensamento de grupo e reacção de aceitação sem objecções préformatadas para seguir o movimento do rebanho, mesmo se isso, como tem acontecido no Iraque, nos leva a cair no precipício.

E isso, pelo seu lado, traz-me de novo à palavra com que comecei: humildade. A verdadeira humildade crítica perante grandes obras de arte. Eu não expliquei Pinter: apenas partilhei convosco algumas reflexões sobre parte da obra de Pinter que me ocorreram ao vê-lo e ao lê-lo ao longo de 35 anos. Se o que eu disse vos levar a ver mais uma peça de Pinter do que fariam sem me ouvir, ou ainda melhor, se vos levar a encenar mais uma das suas peças, e talvez a ter uma nova perspectiva sobre algumas das coisas que estão já lá, na obra de um Mestre, então terei conseguido ir além das minhas expectativas mais queridas. E por essa oportunidade, eu - humildemente vos agradeço.

\section{Referências bibliográficas}

GILLEN, Francis (2006), "Afinidades de espirito: Harold Pinter e a tragédia grega", Sinais de cena, n. ${ }^{\circ}$ 6, Dezembro, pp. 66-72.

PINTER, Harold (1998), Party Time, in Plays 4, London, Faber and Faber, pp. 279-314.

-- (2002a), A colecção, trad. Pedro Marques, in Teatro I, Lisboa, Relógio d'Água, pp. 209-242.

-- (2002b), Há tanto tempo, trad. Jorge Silva Melo, in Teatro I, op. cit., pp. 27-62.

-- (2002c), O regresso a casa, trad. Pedro Marques, in Teatro I, op. cit., pp. 275-338.

-- (2002d), O serviço, trad. Pedro Marques e João Saboga, in Teatro I, op. cit., pp. 109-140.

-- (2002e), Cinza às cinzas, trad. Paulo Eduardo Carvalho, in Teatro II, Lisboa, Relógio d'Água, pp. 207-227.

-- (2006a), Os anões, trad. José Lima, Lisboa, Dom Quixote.

-- (2006b), Os anões, trad. Pedro Marques, in Os anões e outras peças, Vila Nova de Famalicão, Edições Quasi, 2006, pp. 87-113.

QUIGLEY, Austin (1975), The Pinter Problem, Princeton University.

Tradução de Maria Helena Serôdio 